\title{
EDITORIAL
}

\section{Donación y trasplante de órganos en Paraguay}

\author{
Arellano, Nelson ${ }^{1}$ \\ 1 Jefe Unidad Trasplante Hepático. Facultad de Ciencias Médicas, Universidad Nacional de Asunción. San Lorenzo, Paraguay.
}

La palabra donación adquiere su verdadera importancia cuando se la asocia a la palabra trasplante y representa la solidaridad dentro de una sociedad.

Una sociedad donde interactuamos todos sus integrantes y dependemos unos de otros.

Para ilustrar la dependencia de unos y otros, permítanme hablarles de tres protagonistas, que representan a otros tantos, que no se conocen y sin saberlo forman parte de una misma historia, unidos como eslabones de una cadena.

Esta es la historia de la Donación y Trasplante en el Paraguay, donde tres protagonistas: el donante, el paciente en lista de espera y el paciente trasplantado, que representan tres situaciones diferentes, en épocas distintas, están unidos sin embargo con un solo fin, LA VIDA.

- El donante, primer protagonista, primer eslabón: en el mes de septiembre de 1992, sucedía lo irreversible, tras una hemorragia cerebral, un colega, el Dr. Marco Aurelio Aguayo Rodríguez, de 33 años, egresado de nuestra bicentenaria alma mater (1), especializado en el exterior en infectología, se convertía en el primer donante en nuestro país.

Su familia en medio del profundo dolor que les embargaba, nos ofrecía el primer regalo de vida y al mismo tiempo enviaba un mensaje silencioso de solidaridad a la sociedad paraguaya.

El Dr. Aguayo, que nos había dado muestras de su humanismo al tratar a los estigmatizados pacientes con SIDA, habiendo acuñado la frase "Hay que atacar la enfermedad y no a los enfermos", misión que continúan sus allegados gracias a la materialización de uno de sus sueños, la Fundación de lucha contra el SIDA que lleva su nombre (2).

Séneca a través de una de sus citaciones, con una vigencia que sorprende, nos permite recordar y honrar la memoria del Dr. Marco Aguayo "Cuando el sol se eclipsa para desaparecer, se ve mejor su grandeza» (3).

En el momento en que se envió ese primer mensaje de solidaridad, ese primer regalo de vida por el Dr. Aguayo y su familia, tal vez nuestra sociedad no estaba preparada para escuchar.

- El paciente en lista de espera, es el segundo protagonista de esta historia. Ana Almirón Riquelme, una niña, es el segundo eslabón de esta cadena, fallecía en abril del año 2013, aquejada por una enfermedad cardiaca terminal. Con tan solo 6 años de edad, había repetido el mismo mensaje de solidaridad, durante casi dos años, estando en lista de espera, mensaje enviado una primera vez dos décadas atrás por la familia Aguayo, a la misma sociedad, autoridades, médicos, conciudadanos, que se rehusaban a escuchar.

"Anita" con su hermosa e inocente sonrisa esperó largos e interminables meses, su espera fue demasiado larga por un regalo de vida que nunca llegó.

Autor correspondiente: Prof. Dr. Nelson Arellano, Jefe Unidad de Trasplante Hepático. Hospital de Clínicas. Facultad de Ciencias Médicas, Universidad Nacional de Asunción. San Lorenzo, Paraguay. Email: narellanodr@hotmail.fr Fecha de recepción el 20 de Diciembre del 2018; aceptado el 26 de Diciembre del 2018. 
Sus padres, inconsolables por la pérdida, nos seguían mostrando el camino a seguir, decidiendo donar las corneas, transformándose Anita de esta manera, de paciente en lista de espera a donante, ofreciendo lo que nuestra sociedad le había negado.

- El paciente trasplantado, es el tercer protagonista de esta historia, el Sr. Germán Martínez Vierci, periodista, compatriota el, no encontrando respuestas en su país, se ve obligado a viajar al extranjero para beneficiar de un trasplante hepático, sumándose de esta manera el desarraigo a lo grave de su estado de salud, una enfermedad que no conoce ni respeta edades, sexos, religiones ni clases sociales.

El Sr. Martínez Vierci, agradecido por esta nueva oportunidad de vida que le ofrecía el trasplante permitiéndole seguir disfrutando de su familia, inició, impulsó y orquestó con una precisión quirúrgica la "Ley Anita", promulgada en el 2018, intentando con ello evitar que compatriotas sigan padeciendo de las insuficiencias de una estructura de salud que no ofrece soluciones adecuadas a problemas tan complejos, teniendo como copartícipes de este proyecto Docentes dedicados al trasplante de la Facultad de Medicina de la UNA, colegas de otras instituciones, pacientes en lista de espera así como pacientes trasplantados, encontrando en el Parlamento de nuestra nación la caja de resonancia ideal.

Tal vez sea muy pronto para dimensionar los cambios que se generaran a partir de esta nueva ley en la vida de muchos de nuestros conciudadanos aquejados por una enfermedad terminal, tal vez no se vea la calma que nos embarga al despertar una pequeña luz de esperanza a los profesionales dedicados al trasplante, desesperados por una realidad que era difícil de entender, donde el día a día nos quebraba un poco más y nos hacía interrogarnos si nuestros sueños no eran simplemente una quimera, en un país que no merece y sin embargo se encuentra asfixiado por los vicios propios del ser humano.

Todo lo que se pudo hacer, será algún día olvidado y no tiene verdaderamente importancia, lo realmente importante es que para mucha gente habrá un antes y un después de la "Ley Anita", cada vida que vuelva a nacer luego de una donación será una nueva victoria, cada sonrisa de una madre que ve a su hijo recuperado lo será también.

La "Ley Anita", que lejos de ser una ley coercitiva, simplemente nos recuerda que como partes integrantes de una sociedad, tenemos derechos pero al mismo tiempo obligaciones, y debemos de tomar un minuto de nuestro tiempo, discutir en familia y tomar una decisión: ser donantes o no.

La citada ley, reglamenta no solamente la donación, sino también el trasplante, demostrando como si fuera necesario, que aislada la donación no tiene significado, así como los eslabones de una única cadena, de una misma historia que debe contar con todos sus actores para que sea completa.

En cuanto a los profesionales de la salud dedicados a la Donación y al Trasplante, soy un convencido de que somos simplemente actores secundarios, intermediarios privilegiados de esta historia de máxima expresión de amor y solidaridad entre dos seres humanos, dos familias, dentro de una sociedad, donde una persona le ofrece a otra, sin conocerla y sin pedir nada a cambio la posibilidad de seguir viviendo.

Finalmente, deberíamos decidir como ciudadanos de una sociedad que se quiere solidaria, si deseamos ser protagonistas de esta que es nuestra historia, o ser simplemente observadores y críticos al costado del camino.

\section{Y si todos fuéramos "Anita"}

Prof. Dr. Nelson Arellano - Editor Invitado

\section{REFERENCIAS BIBLIOGRAFICAS}

1. http://dle.rae.es/?w=alma+mater

2. https://www.facebook.com/fundacion.marcoaguayo

3. El libro de los Valores / The Book of Values. Ilustrado por Sandra Ardila. Ediciones Robinbook, 2005. ISBN 9788493423056. p. 157. 


\title{
EDITORIAL
}

\section{Donation and transplant of organs in Paraguay}

\author{
Arellano, Nelson \\ Jefe Unidad Trasplante Hepático. Facultad de Ciencias Médicas, Universidad Nacional de Asunción. San Lorenzo, Paraguay.
}

The word donation acquires its true importance when it is associated with the word transplant and represents solidarity within a society. A society where all its members interact and we depend on each other.

To illustrate the dependence, allow me to talk about three protagonists, who represent many others, who do not know each other and unknowingly form part of the same story, united as links of a chain.

This is the story of Donation and Transplant in Paraguay, where three protagonists: the donor, the patient on the waiting list and the transplanted patient, who represent three different situations, at different times, are nevertheless united with a single purpose, LIFE.

- The donor, first protagonist, first link: in September 1992, the irreversible happened, after a brain hemorrhage, a colleague, Dr. Marco Aurelio Aguayo Rodríguez, 33 years old, a graduated of our bicentennial alma mater (1), specialized abroad in infectology, became the first donor in our country.

His family in the midst of sorrow, offered us the first gift of life and at the same time sent a silent message of solidarity to the Paraguayan society.

Dr. Aguayo, gave us profs of his humanism by treating the stigmatized patients with AIDS and by phrases like "We must attack the disease and not the sick", a mission that his close ones continue through one of his dreams, AntiAIDS Foundation that bears his name (2).

Seneca through one of his quotes, with a surprising long-lasting force, allows us to remember and honor the memory of Dr. Marco Aguayo «When the sun is eclipsed to disappear, you can see its greatness» (3).

At the time that first message of solidarity was sent, that first gift of life by Dr. Aguayo and his family, perhaps our society was not prepared to listen.

- The patient on the waiting list is the second protagonist of this story. Ana Almirón Riquelme, a girl, is the second link of this chain, she died in April 2013, suffering from a terminal heart disease. With only 6 years old, she repeated the same message of solidarity for almost two years being on the waiting list, message sent a first time two decades ago by the Aguayo family, to the same society, authorities, doctors and fellow citizens, who refused to listen.

"Anita" with her beautiful and innocent smile waited for long and endless months, she waited for too long for a gift of life that never came.

Her parents, devastated by their loss, kept showing us the path to follow, deciding to donate the girl's corneas, transforming Anita, from patient on waiting list to donor, offering what our society had denied her. 
- The transplanted patient, is the third protagonist of this story, Mr. German Martínez Vierci, journalist and fellow citizen, not finding answers in his country, is forced to travel abroad for a liver transplant, adding the distance and displacement to his serious preexisting condition, a disease that does not discriminate ages, sexes, religions or social classes.

Mr. Martinez Vierci, grateful for the new life opportunity offered to him in the form of a transplant that allowed him to continue enjoying his family, initiated, promoted and orchestrated with surgical precision the "Anita Law", promulgated in 2018; all of this in the attempt to avoid the suffering of our people whom already suffer from the inadequacies of a health structure that did not offer adequate solutions for such complex problems; having as partners in this project Faculty of the School of Medicine of the University of Asuncion dedicated to transplants, colleagues from other institutions, patients on the waiting list as well as transplanted patients, finding in the Parliament of our nation the ideal auditorium.

It may be too early to understand the changes that this law will generate in the lives of many of our fellow citizens suffering from a terminal illness, and maybe it isn't evident the calm brought by a small light of hope that overwhelms us as professionals dedicated to organ transplant, within a desperate and difficult to understand reality, where the day by day broke us a little more each day and even made us wonder if our dreams were not just a pipe dream, in a non-deserving country suffocated by the vices of the human kind.

Everything that could and could not be done, will one day be forgotten and it doesn't really matter, the important thing is that for many people there will be a before and after the "Anita Law". Every reborn person after a donation will be a new victory, every smile of a mother who sees her son recovered will be too.

The "Anita Law", far from being a coercive law, simply reminds us we are an integral parts of a society, we have rights but at the same time obligations, and we must take a minute of our time, and discuss as a family and make a decision: to be donors or not.
The aforementioned law covers not only the donation, but also the transplant, demonstrating as if it were necessary, that the donation has no meaning without a transplant, as a chain of a single link, as a story without all of its characters.

Regarding the health professionals dedicated to Donation and Transplant, I am convinced that we are simply supporting actors, privileged intermediaries of this maximum expression of love and solidarity between two human beings, two families, within one society, where one person, without knowing the person and without asking anything in return, offers another the opportunity to live.

Finally, we should decide as citizens, if we want to be protagonists of our own history, member of a society that wants to be solidary or simply be observers and critics at the side of the road.

\section{And if we were all "Anita"}

Prof. Dr. Nelson Arellano - Editor Invitado

\section{BIBLIOGRAPHIC REFERENCES}

1. http://dle.rae.es/?w=alma+mater

2. https://www.facebook.com/fundacion.marcoaguayo

3. The Book of Values / The Book of Values. Illustrated by Sandra Ardila. Editions Robinbook, 2005. ISBN 9788493423056. p. 157. 